\title{
Plant Selection Behavior and Promotion Use by Garden Center Customers ${ }^{1}$
}

\author{
Hayk Khachatryan, Alicia Rihn, and Xuan Wei ${ }^{2}$
}

\section{Introduction}

Consumers utilize many different behaviors while shopping for goods. For instance, impulse buying occurs when a consumer is overwhelmed with the sudden desire to purchase a product (Rook and Fisher 1995). Impulse buyers are of particular interest because $68 \%$ of all purchases are unplanned (Ståhlberg and Maila 2010) and impulse buyers contribute $\$ 4$ billion in annual retail sales (Mogelonsky 1998). Price consciousness is another behavior where the consumer focuses on the product's price more than other product attributes (Sinha and Batra 1999). In the ornamental plant industry, research has demonstrated that consumer selection of plants is greatly impacted by both of these shopping behaviors (Khachatryan et al. 2018; Hall et al. 2010). Khachatryan et al. (2018) demonstrated that impulse buyers are less likely to purchase plants. Hall et al. (2010) found that consumers frequently utilize price when determining if they will purchase an ornamental plant. Additional studies demonstrate another type of shopping behavior, when consumers plan ahead and use plant quality and aesthetic characteristics to determine their product selections (Brand and Leonard 2001; Kelley et al. 2001). Each of these studies demonstrates the potential impact of established shopping behaviors on consumers' plant selections in a retail setting. However, the studies do not connect existing shopping behavior to promotion effectiveness in the garden center.
Promotion effectiveness is of interest because firms spend a fair amount on promotions in the hopes of capturing consumer attention and sales. Previous research shows promotions influence consumers' decisions to shop at certain stores and purchase particular items (Brand and Leonard 2001; Kiran et al. 2012). In garden centers, multiple studies have demonstrated the positive impacts of promotions on consumers' purchasing decisions (Brand and Leonard 2001; Niemiera et al. 1993; Stegelin 2001). However, other studies caution that promotions may go unnoticed by end consumers (Collart et al. 2013; Nordfält and Lange 2013). Given the resources allocated to promotions, understanding their effectiveness in reaching consumers and their use is of particular interest to firms.

This study explores the relationship between consumers' plant selection behavior (i.e., shopping behavior) and ways that promotions affect subsequent activities. Specifically, we utilized three different selection behaviors (planners, impulsive, and price-sensitive) to investigate how various types of promotions impact store visit likelihood, product selection, and number of plants purchased. Results are useful for garden centers and other green industry retailers as they decide on their marketing strategies.

1. This document is FE1098, one of a series of the Food and Resource Economics Department, UF/IFAS Extension. Original publication date May 2021. Visit the EDIS website at https://edis.ifas.ufl.edu for the currently supported version of this publication.

2. Hayk Khachatryan, associate professor and Extension economist, UF/IFAS Mid-Florida Research and Education Center; Alicia Rihn, assistant professor, Agricultural and Resource Economics, University of Tennessee; and Xuan Wei, postdoctoral researcher, UF/IFAS Mid-Florida REC; UF/IFAS Extension, Gainesville, FL 32611.

The Institute of Food and Agricultural Sciences (IFAS) is an Equal Opportunity Institution authorized to provide research, educational information and other services

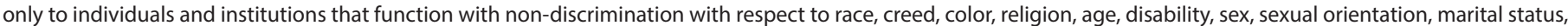

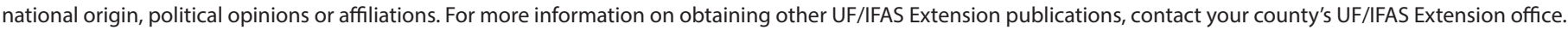
U.S. Department of Agriculture, UF/IFAS Extension Service, University of Florida, IFAS, Florida A \& M University Cooperative Extension Program, and Boards of County Commissioners Cooperating. Nick T. Place, dean for UF/IFAS Extension. 


\section{Data Collection}

An online survey was used to reach 1,680 Florida plant purchasers in October-November 2017. The online survey consisted of three broad sections: plant selection behavior, promotions, and demographics.

The plant selection behavior section contained nine statements that captured respondents' existing primary strategies that they used when selecting plants. Respondents were asked to indicate how characteristic each statement was of themselves ( $1=$ not at all characteristic; $7=$ very characteristic). The existing strategies included "planned" (respondents knew the plants, colors, or designs they wanted prior to shopping), "impulsive" (respondents did not plan ahead and impulse-purchased plants at the retailer), and "pricesensitive" (respondents primarily focused on prices when shopping for plants).

The promotions section contained three questions to capture how different types of promotions influenced respondents' store visit likelihood, plant purchase likelihood, and number of plants purchased. For the store visit likelihood, the promotions included in-store, mass media, online, and value-added program options. They were asked to rate each on a 7 -point scale where $1=$ very ineffective and $7=$ very effective at prompting them to visit the store. The plant purchase likelihood question contained comparable promotions and asked respondents to rate how each promotion would impact their purchase likelihood for a specific plant using a 7 -point scale where $1=$ very unlikely and $7=$ very likely. Lastly, the number of plants purchased question utilized monetary promotions and a 7-point scale where $1=$ very negative impact (on the number of plants purchased) and $7=$ very positive impact.

The demographics section asked respondents their age, gender, household size, education, and 2016 income. The demographic results for the total sample and each group (planned, impulsive, and price-sensitive) can be viewed in Table 1.

Ordered logit models were used to estimate the results for how different types of promotions influenced respondents' store visit likelihood, plant purchase likelihood, and number of plants purchased for each group. For the store visit likelihood, a positive (negative) result indicates greater (lower) likelihood of visiting. For the plant purchase likelihood, a positive (negative) result indicates greater (lower) likelihood of purchasing. For the number of plants purchased, a positive (negative) result indicates more (fewer) plants purchased.

\section{Results}

\section{Encouraging Garden Center Visit Likelihood}

Visiting a garden center is one of the first steps needed for a sale to occur. Results demonstrate that different plant selection groups respond differently towards promotions designed to encourage them to visit garden centers (Figure 1). Members of the planned group respond positively to printed ads, radio/TV ads, educational programs, outside signage, past experiences, and loyalty programs when compared to online ads. They respond negatively to financial incentives, in-store events, and word-of-mouth advertising.

Members of the impulsive group are encouraged to visit garden centers through print ads, in-store events, in-store information, outside signage, positive past experiences, word of mouth, and loyalty programs when compared to online ads. However, they are discouraged by the use of educational programs.

Price-sensitive group members are most encouraged to visit garden centers by promotions utilizing print ads, coupons and financial incentives, in-store events, and outside signage when compared to online ads. However, the use of radio/TV ads, in-store information, educational programs, past experiences, word of mouth, and loyalty programs reduced their likelihood of visiting a garden center.

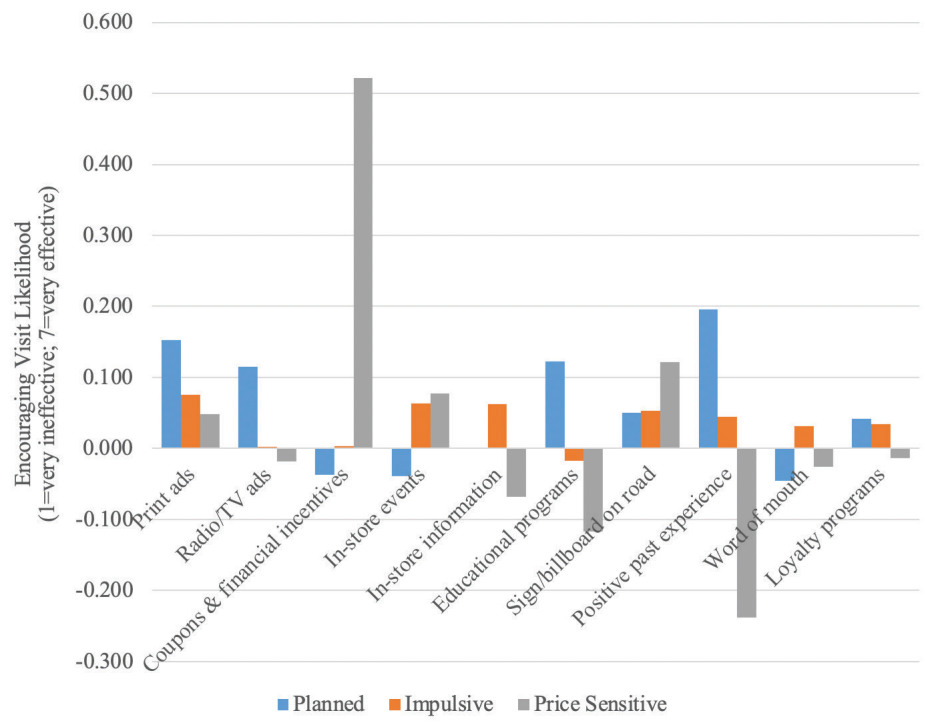

Figure 1. Promotions' effectiveness on encouraging garden center visits. Note: All results were significant at $10 \%$ when compared to "online advertisements" with the exceptions of the in-store information for the planned group and the radio/TV ads and coupons/ financial incentives for the impulsive group.

Credits: UF/IFAS 


\section{Plant Purchase Likelihood}

After consumers are in the garden center, the next step is to encourage them to purchase plants. The impact of promotions on plant purchase likelihood demonstrates that planners are positively impacted by print ads, radio/ TV ads, in-store tags/labels, staff recommendations, and plant brands when compared to online ads (Figure 2). They are less likely to buy plants promoted with coupons, sales, demonstrations/examples, and in-store signs.

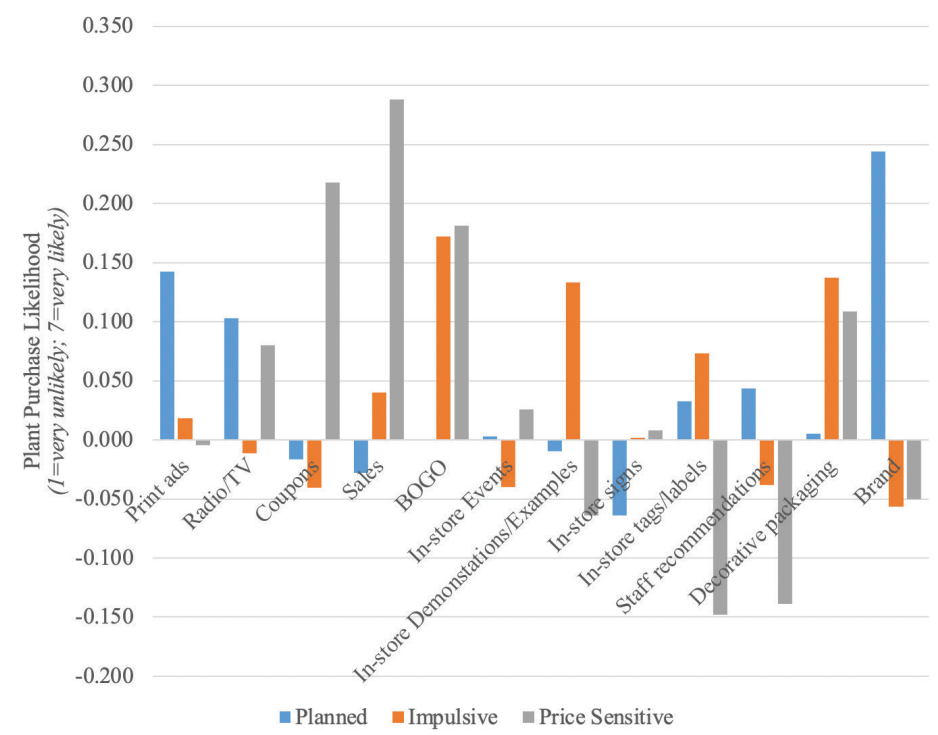

Figure 2. Promotions' effect on plant purchase likelihood. Note: All results were significant at $10 \%$ when compared to the "online advertisements" except for the BOGO, in-store events, and decorative packaging for planners, in-store signs for the impulsive group, and print ads and in-store signs for the price-sensitive group.

Credits: UF/IFAS

For impulsive group members, they are more likely to purchase plants that are promoted with print ads, sales, BOGO, demonstrations/examples, in-store tags/labels, and decorative packaging when compared to online ads. Conversely, radio/TV ads, coupons, in-store events, staff recommendations, and plant brands decrease their purchase likelihood.

Lastly, price-sensitive shoppers are more likely to buy plants promoted with radio/TV ads, coupons, sales, BOGO, instore events, and decorative packaging when compared to online ads. They are less likely to purchase plants promoted with in-store demonstrations/examples, in-store tags/labels, staff recommendations, and brands. These last promotions are often used to emphasize value-added characteristics that may reflect higher prices. This likely discourages pricesensitive consumers from responding positively to these promotions.

\section{Number of Plants Purchased}

Lastly, the influence of monetary promotions on the number of plants purchased was addressed. All three groups responded positively to percent-off coupons, BOGO promotions, and slash-through pricing when compared to sales (in general; Figure 3). The planned group responded most positively to the percent-off coupons. Impulsive consumers responded the most positively to the slash-through sales, followed by BOGO. Lastly, the price-sensitive consumers responded the most positively to the slash-through sales, followed by BOGO, and finally the percent-off coupons.

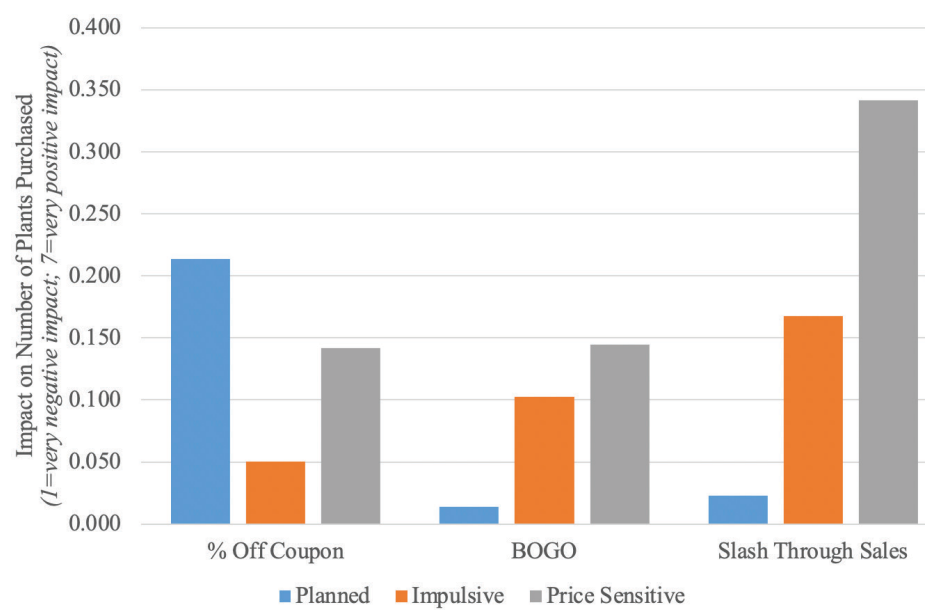

Figure 3. Promotions' effect on number of plants purchased. Note: All results were significant at the $10 \%$ level when compared to "sales." Credits: UF/IFAS

\section{Summary}

Preexisting plant selection behaviors influence how effective different types of promotions are at affecting consumers' behavior. Specifically, we observed that planners were more encouraged to visit garden centers and purchase plants by promotions that were available ahead of time (e.g., printed ads, educational programs, etc.). This is not surprising given the group's tendency to plan their purchases prior to their shopping trips. Conversely, impulsive group members were more affected by in-store events and information, both of which have been shown to encourage impulsive buying behavior (Punj 2011; Rostocks 2003). Lastly, price-sensitive group members were most positively impacted by financial incentives (e.g., coupons, sales, etc.), which align with this group's focus on price.

Overall, the results have real-world implications for garden centers that want to direct their promotional efforts at a specific group of consumers (i.e., target marketing). Specifically, retailers targeting the planned group should utilize promotions that are accessible to this group and available well in advance. For those who want to reach the 
impulsive consumer, eye-catching in-store promotions and signs need to be used to encourage purchases. Lastly, retailers interested in attracting price-sensitive consumers can encourage store visits through print media, monetary incentives, events, and signage, then offer in-store monetary promotions to encourage additional sales.

\section{References}

Brand, M. H., and R. L. Leonard. 2001. "Consumer Product and Service Preferences Related to Landscape Retailing."

HortScience 36:1111-1116.

Collart, A. J., M. A. Palma, and C. E. Carpio. 2013.

"Consumers' Response to Point of Purchase Advertising for Local Brands." Journal of Agricultural and Applied Economics 45:229-242.

Hall, C. R., B. Campbell, B. K. Behe, R. G. Lopez, and J. H. Dennis. 2010. "The Appeal of Biodegradable Packaging to Floral Consumers.” HortScience 45:583-591.

Kelley, K. M., B. K. Behe, J. A. Biernbaum, and K. L. Poff. 2001. "Consumer Preference for Edible-Flower Color, Container Size, and Price." HortScience 36:801-804.

Khachatryan, H., A. Rihn, B. Behe, C. Hall, B. Campbell, J. Dennis, and C. Yue. 2018. "Visual Attention, Buying Impulsiveness, and Consumer Behavior." Marketing Letters (accepted).

Kiran, V., M. Majumdar, and K. Kishore. 2012. "Innovation in In-Store Promotions: Effects on Consumer Purchase Decision." European Journal of Business and Management 4:36-44.

Mogelonsky, M. 1998. "Keep candy in the aisles." American Demographics 20(1): 32.

Niemiera, X. A., J. Innis-Smith, and C. E. Leda. 1993.

"Survey of Garden Center Customer Informational and Marketing Needs." Journal of Environmental Horticulture 11:25.

Nordfält, J., and F. Lange. 2013. "In-Store Demonstrations as a Promotion Tool." Journal of Retailing and Consumer Services 20:20-25.

Punj, G. 2011. "Impulse Buying and Variety Seeking: Similarities and Differences." Journal of Business Research 64(7): 745-748.
Rook, D. W., and R. J. Fisher. 1995. "Normative Influences on Impulsive Buying Behavior." Journal of Consumer Research 22:305-313.

Rostocks, L. 2003. "Tapping into the Shopper Impulse." Canadian Grocer 117(8).

Sinha, I., and R. Batra. 1999. "The Effect of Consumer Price Consciousness on Private Label Purchase." International Journal of Research in Marketing 16:237-251.

Ståhlberg, M., and V. Maila (ed.). 2010. Shopper Marketing: How to Increase Purchase Decisions at the Point of Sale. Philadelphia: Kogan Page Publishers.

Stegelin, F. 2001. "Role of Point-of-Sale Information on Consumers' Purchase Decisions." SNA Research Conference 46:536-538. 
Table 1. Sample demographic statistics.

\begin{tabular}{|c|c|c|c|c|}
\hline & \multicolumn{4}{|c|}{ Group } \\
\hline & Total Mean & $\begin{array}{l}\text { Planned } \\
\text { Mean }\end{array}$ & $\begin{array}{l}\text { Impulsive } \\
\text { Mean }\end{array}$ & $\begin{array}{c}\text { Price-Sensitive } \\
\text { Mean }\end{array}$ \\
\hline$\%$ of sample & $100.0 \%$ & $63.3 \%$ & $52.3 \%$ & $50.2 \%$ \\
\hline Age (in years) & 51.93 & 51.77 & 52.02 & 50.21 \\
\hline Gender (\% female) & $60 \%$ & $58 \%$ & $67 \%$ & $59 \%$ \\
\hline Household size & 2.56 & 2.60 & 2.58 & 2.62 \\
\hline Education-4-year degree or higher & $50 \%$ & $50 \%$ & $46 \%$ & $48 \%$ \\
\hline 2016 household income & $\$ 62,600$ & $\$ 64,800$ & $\$ 62,200$ & $\$ 60,300$ \\
\hline
\end{tabular}

a Participants can belong to more than one group. 